biosynthesis of the vitamin, or to other causes, requires further investigation.

The low intake of niacin by Bantu breast-fed babies is not apparently deleterious, for local pediatricians aver that there is parity of growth and general health between Bantu and European babies when exclusively breast-fed up to six months.

There is no statistical difference between the mean concentrations of tryptophan in the breast milks of the Bantu and European mothers (groups 1 and 4).

The determinations of niacin and tryptophan were carried out by Mr. G. Smith and Miss H. S. P. Snyman, of the South African Bureau of Standards, Pretoria. This communication is published with the permission of the South African Council for Scientifio and Industrial Research.

Human Biochemistry Unit,

A. R. P. WALKER

South African Council for

Scientific and Industrial Research,

South African Institute for Medical Research, Johannesburg. Oct. 17.

${ }^{1}$ Goldsmith, G. A., Sarett, H. P., Register, U. D., and Gibbins, J., J. Clin. Invest., 31, 553 (1952).

' Klein, J. R., Perlzweig, W. A., and Handler, P., J. Biol. Chem. 145, 27 (1942).

s Kropman, M. "Studies in the Vitamin Content of African Food stuffs", M.S̈c. thesis, University of South Africa (1946).

- Macy, I. G., Amer. J. Dis. Child., 78, 589 (1949).

'Smit, R., S. Afr. Med. J., 24, 258 (1950):

" Gyorgy, P., "Vitamin Methods", 1 (New York, Acad. Press, 1950).

"Greene, R. D., and Black, A., J. Biol. Chem., 155, I (1944).

"Fox, F. W., and Golberg, L., "South African Food Tables", Pub. S. Afr. Inst. Med. Res., 9, No. 46 (1944).

- MeLester, J. S., and Darby, W. J., "Nutrition and Diet in Health and Disease" (6th edit., Philadelphia, Saunders, 1952).

${ }^{10}$ Kodicek, E., and Chaudhuri, D. K., Nature, 165, 1022 (1952). "1 Walker, A. R. P., Arvidsson, U. B., and Draper, W. L., Lancet, i,
317 (1952).

\section{Formation of Enzymatically Active, Dialysable Fragments during Autodigestion of Pepsin}

Northrop and co-workers have shown ${ }^{1}$ that pepsin in solution digests itself with the formation of material soluble in trichloroscetic acid. The amount of nonprotein substance formed depends upon factors such as time, temperature, and the $p \mathrm{H}$ and composition of the solvent. It has now been found in this laboratory that if autodigestion of pepsin proceeds at $p \mathrm{H}$ values removed from those optimal for proteolysis, $p H 1 \cdot 5-2 \cdot 0$, activity can be recovered in the non-protein fraction.

In \& typical experiment, $0 \cdot 6 \mathrm{gm}$. Worthington crystalline pepsin is dissolved in $60 \mathrm{ml} .0 \cdot 1 \mathrm{M}$ sodium acetate buffer of $p H \mathbf{H \cdot 6}$. The solution is then incubated at $37^{\circ} \mathrm{C}$. and $10-\mathrm{ml}$. samples are withdrawn at intervals of $12,18,24,30,36$ and $48 \mathrm{hr}$. and quickly chilled to $5^{\circ} \mathrm{C}$. A portion of each sample is next dialysed at the low temperature for $24 \mathrm{hr}$., against $2 \cdot 5$ volumes of the acetate buffer. With the aid of the hæmoglobin method ${ }^{2}$, the activities of the protein, both before and after dialysis, and of the dialysate are determined. Enzymatically active fragments are found in the dialysate after incubation at $37^{\circ} \mathrm{C}$. for $24-48 \mathrm{hr}$. This material represents $10-20$ per cent of the total protein and has an activity, per unit of nitrogen, of 1-5 per cent relative to that of the intact enzyme. The dialysable material is inactivated on heating to $100^{\circ} \mathrm{C}$. for five minutes or on prolonged incubation at $37^{\circ} \mathrm{C}$. After passage of the hydrolysate through a column of 4 per cent cross-linked 'Dowex 50', at

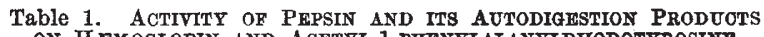
ON HAMOGLOBIN AND ACETYL-1-PHENYLALANYLDIODOTYROSINR

\begin{tabular}{|c|c|c|c|c|}
\hline \multirow{2}{*}{ Preparation } & \multirow{2}{*}{$\begin{array}{l}\text { Time of } \\
\text { incuba- } \\
\text { tion at } \\
37^{\circ} \mathrm{C} . \\
\text { (hr.) }\end{array}$} & \multirow{2}{*}{$\begin{array}{l}\text { mgm. } \\
\text { Nitrogen } \\
\text { per ml. of } \\
\text { solution }\end{array}$} & \multicolumn{2}{|c|}{$\begin{array}{l}\text { Relative speciflc pro- } \\
\text { teolytic activity per } \\
\text { unit nitrogen* }\end{array}$} \\
\hline & & & $\begin{array}{c}\text { Hæmo- } \\
\text { globin }\end{array}$ & $\begin{array}{l}\text { Synthetic } \\
\text { substrate }\end{array}$ \\
\hline Pepsin, control & 0 & 1.35 & 100 & 100 \\
\hline $\begin{array}{l}\text { Pepsin } \\
\text { Pepsin, dialysed } \\
\text { Dialysate }\end{array}$ & 9 & $\begin{array}{l}1 \cdot 32 \\
1 \cdot 28 \\
0 \cdot 1 \dagger\end{array}$ & $\begin{array}{r}96 \\
110 \\
0\end{array}$ & $\begin{array}{c}\text { not tested } \\
\text { not tested } \\
\mathbf{0}\end{array}$ \\
\hline $\begin{array}{l}\text { Pepsin } \\
\text { Pepsin, dialysed } \\
\text { Dialysate }\end{array}$ & 48 & $\begin{array}{l}1 \cdot 34 \\
1 \cdot 16 \\
0 \cdot 2 \dagger\end{array}$ & $\begin{array}{r}97 \\
92 \\
3\end{array}$ & $\begin{array}{r}95 \\
100 \\
64\end{array}$ \\
\hline
\end{tabular}

* The relative speciflc activity of a freshly prepared dialysed enzyme * The relative speciffc
solution is taken as 100 .

+ Nitrogen values of the dialysate refer to $1 \mathrm{ml}$. of the original protein solution.

least two active components are isolated from the eluate. Similar results have been obtained with five crystalline preparations of pepsin, although the amount of active dialysable material found on incubation varies somewhat with the length of storage of the crystalline enzyme. In all these experiments, tests for bacterial contamination were made in order to eliminate this as a source of activity.

Although, as indicated with a typical experiment listed in Table 1, the activity of the dialysable fraction against hæmoglobin is low, that against the synthetic substrate acetyl-1-phenylalanyldiiodotyrosine ${ }^{3}$ is 64 per cent of the value for the intact protein. It thus seems reasonable to suppose that the active fragments may represent a portion of the original protein with an amino-acid configuration specific for the hydrolysis of a peptide bond adjacent to a tyrosine residue. In contrast, the low activity against the protein substrate may be taken as an indication that proteolysis of hæmoglobin involves a variety of types of bonds, for some of which the dialysable fragment has a reduced activity.

I wish to thank Dr. Lillian E. Baker for a generous sample of acetyl-1-phenylalanyldiiodotyrosine and Dr. Lewis G. Longsworth for suggestions during preparation of the manuscript.

\section{Gertrude F.. Perlmann}

Rockefeller Institute for Medical Research, New York.

Oct. 27.

${ }^{2}$ Herriott, R. M., Desreux, V., and Northrop, J. H., J. Gen. Physiol., $24,213(1940)$

"Northrop, J. H., Kunitz, M., and Herriott, R. M., in "Crystalline Enzymes," 74 and 81 (2nd edit., Columbia Úniversity Press, New York).

- Baker, L. E., J. Biol. Cherr., 193, 809 (1951).

- Fruton, J. S., and Bergmann, M., J. Biol. Chem., 127, 627 (1939).

\section{Effect of Temperature on Leaf-shape in Ranunculus}

IN trifoliate species of Ranunculus the first-formed and juvenile leaves are undivided, and as the plants mature the adult trifoliate or biternate condition is gradually taken up by new leaves. Quite frequently, however, some of the later leaves of mature plants show a partial reversion to a less divided, more juvenile form. This reversion may occur in leaves of similar age in many plants in a single area, which suggests a temporary or seasonal environmental cause.

An investigation has recently been carried out to determine the separate effects upon leaf-dissection 